\title{
English Language Speaking Skill Issues in an EMP Context: Causes and Solutions
}

\author{
Mohammed Abdulgalil Abugohar ${ }^{1}$, Ma'in Ateyah Al-Hnifat ${ }^{1}$, Omar Ali Al-Smadi ${ }^{1}$, Radzuwan Ab Rashid ${ }^{1}$ \& \\ Kamariah Yunus ${ }^{1}$ \\ ${ }^{1}$ Faculty of Languages and Communication, Universiti Sultan Zainal Abidin (UniSZA), Malaysia \\ Correspondence: Mohammed Abugohar, Faculty of Languages and Communication, Universiti Sultan Zainal \\ Abidin, 21300 Kuala Nerus, Terengganu, Malaysia. E-mail: modyjau@yahoo.com
}

Received: March 8, 2019 Accepted: March 31, 2019 Online Published: April 20, 2019

doi:10.5539/ijel.v9n3p211 URL: https://doi.org/10.5539/ijel.v9n3p211

\begin{abstract}
A good start in researching on language teaching and learning issues is to first analyse target learners' actual performance and their needs. This mixed-methods 2-cycle study is aimed to analyse medical-college students' language needs through two instruments - a self-rated report and a guided focus group. Out of the main four language skills (speaking, reading, listening, and writing), Cycle 1 aimed at exploring the most trouble-provoking skill for EMP students through a 7-item rating report with a sample of 45 participants. Based on the results of Cycle 1 which labelled speaking as the most problematic language skill for the target learners, Cycle 2 proceeded with 9 interviewees to narrow the study focus on the factors contributing to the inefficiency of speaking skills among EMP learners, discussing solutions from the learners' perspectives. Pedagogically, this research helps practitioners innovate and integrate new techniques in language teaching and learning to overcome the issue of students' speaking performance that has been deemed below expectations.
\end{abstract}

Keywords: EMP context, oral production, speaking skill issues, English speaking problems, causes and solutions

\section{Introduction}

Speaking is one of the main four language skills (speaking, reading, listening, and writing). It is a communicating process of interaction which is the foundation of all relationships between humans. People who talk a language are called speakers of that language. Speaking is very crucial in second or foreign language learning. Mastering oral skills within the learning process is the most significant aspect of learning a language on which the whole process is assessed; based on the skill to perform a conversation in the target language (Leong \& Ahmadi, 2017; Nunan, 1995). Nowadays, in the era of electronic communication and mass media, most data exchanged among people occurs through oral communication. So, out of the four main skills in language learning mentioned earlier, speaking looks to be the most significant one.

English oral proficiency is universally viewed as a marker of success; and the Arab world is no exception. A good level of competence in speaking is a pre-requisite for having better jobs here and there. Brown and Yule (1983) stated that oral language is commonly viewed as one of the most difficult components of language learning.

In spite of its significance, speaking has been ignored or devalued in schools and universities because of several reasons such as insufficient classroom practices and traditional teaching techniques of chalk and talk. Moreover, true assessment of speaking has been absent from language testing for decades due to the difficulty of evaluating it objectively, and the time it consumes to run speaking tests (Clifford, 1987). Unfortunately, speaking is not a significant part of language instructors' tests.

\subsection{Speaking Definition}

Many specialists define speaking in different ways. Chaney and Burk (1998) define speaking as "the process of building and sharing meaning through the use of verbal and non-verbal symbols into a variety of context" (p. 13). Another definition is that "speaking is to express the needs-request, information, service, etc." (Brown \& Yule, 1983). So, speaking is not a simple task; it needs a lot of practice and experience. Luama (2004) says that "speaking in a foreign language is very difficult, and speaking competence takes a long time to develop" (p. 1). 


\subsection{Speaking Skills}

Speaking has many skills and characteristics. Of speaking various skills, two main skills are discussed here. The first skill of speaking is fluency, and it is the key goal of instructors in teaching speaking skills. Language fluency is of major importance in foreign language learning. According to Hughes (2002), fluency is a bidirectional process in which speakers and receivers aim to communicate effectively.

Accuracy is the second speaking skill to shed light on. Accuracy should be accounted for in teachers' route of tutoring. Students should focus on the completeness and the exactness of form of language when speaking; such as emphasizing on pronunciation, vocabulary, and grammatical structures (Mazouzi, 2013). Grammaticality of an utterance entails correct long complex structures (Thornbury, 2005). On the other hand, the accuracy of lexis demands the correct usage of context and terms. Therefore, students' lack of lexical items makes them use the same words in different settings to express the intended meaning (Thornbury, 2005).

Mazouzi (2013) stresses on the equality between accuracy and fluency achievement in the activities and tasks assigned to learners. Both accuracy and fluency are important foundations of the communicative language teaching (CLT) approach (Leong \& Ahmadi, 2017). Classroom practices ought to assist learners in developing and improving their communicative competence. Consequently, language learners should recognize how the language pattern works appropriately and properly. Moreover, mastering other skills such as intonation, pitch, and stress helps students speak the English language the right way effectively and naturally.

\subsection{Problem Statement}

Speaking is one of the most prominent skills in language learning (Ur, 1996) and it is one of the main fundamentals of interaction. In EFL contexts, speaking requires special instruction and attention. Nowadays, speaking is commonly seen as the most essential skill to obtain and acquire. Speaking in English for EFL learners is not an easy mission; it requires much effort to produce acceptable utterances and sentences in English.

Therefore, the main goal of English language teaching is to promote students' abilities to use L2 correctly and effectively in communication (Davies \& Pearse, 2000). Even though practice eliminates learners' shyness (Bashir, Azeem, \& Dogar, 2011), oral activities are often overlooked in classroom practices (Leong \& Ahmadi, 2017). Students do not have sufficient opportunities to practise oral production; neither in their classes nor outside.

In conclusion, speaking is believed to be the most challenging language skill which students face. As stated by Bueno, Madrid, and Mclaren (2006), lots of students have studied English for years but still face major difficulties in speaking appropriately and correctly. Thus, like other non-natives, most Saudi students meet certain difficulties in developing and improving their speaking skills, which hinder them from effectively communicating and interacting orally (Abugohar \& Yunus, 2018; Rabab'ah, 2005). For EMP learners, mastering English oral skills is essential for their study and their future career. Therefore, this study addresses speaking skill in the EMP Saudi context and the difficulties related to their oral performance.

\section{Literature Review}

Many studies have explored oral skills and speaking activities in EFL classrooms in general, and the difficulties faced by university learners in particular. For example, Al-Jamal and Al-Jamal (2014) explored the obstacles that may be faced at six Jordanian governmental universities by gathering the data through semi-structured interviews and a questionnaire, and showed that most students encountered challenges such as shortage of speaking time, the weakness of oral skill, and crowded classrooms as the most highlighted reasons.

Another study by Gan (2012) investigated the difficulties to speaking skills encountered by English-majored learners in Hong Kong University and revealed that the participants significantly faced several difficulties leading to their drawbacks of fluent speaking and oral performance such as concentrating much on grammar structures, lacking vocabulary and out-of-class speaking English environment, and lacking in-class speaking chances. The study concluded the need to incorporate sufficiently intensive language development sections in the English program.

Also, Izadi (2015) explored the views of instructors and learners of English concerning speaking problems among Iranian learners. The study mainly analysed the problems with regard to the opportunities to speak English, negative emotions, and linguistic problems. The main cause appeared from the results was linguistic problems. So, the study offered several solutions to handle with them through the emphasis on instructor's and learners' efforts which were also reconfirmed and justified as possible measures in Kabir (2014) in Bangladesh context, beside more supports from managers. 
Further, Le (2011) explored the same study concern in the setting of Ba Ria-Vung Tau University in Vietnam where students encountered obstacles in English language speaking skills. The results emphasised the obstacles with regard to students' issues such as language proficiency, worries, and learning styles; lecturers' issues such as teaching methodology; and teaching facilities. Moreover, Ngo (2011) investigated speaking problems among Thai Nguyen University students. The study essentially emphasised on three probable challenging aspects: linguistic, psychology, and social culture. The same proposals as Izadi (2015) and Kabir (2014) were recommended for both instructors' and managers' assistance to improve learners' speaking performance. Moreover, although Nguyen and Tran's (2015) research was slightly different from prior studies with regard to high school learners' English-speaking obstacles, the results similarly considered difficulties stemmed from students' weaknesses in speaking English and recommended the necessity of instructors' ready supports by expanding their teaching tasks and activities.

In the context of this research, Saudi Arabia, Soomro and Farooq (2018) investigated the effect of several factors related to learners, teachers, and learning environment on learners' attitude to learning oral and speaking skills. The data collected by using a questionnaire from 184 undergraduate EFL female and male learners at Taif University in Saudi Arabia. The results revealed that the poor level of students' skills in speaking English is contributed to the variety of environment, learners' and teachers' related factors such as the classroom environment or settings that do not completely facilitate both the female and male learners to learn speaking and oral skills in a better way as well as the shortage of measures on the part of learners and teachers. Therefore, these factors impact negatively the approach and attitude of students towards learning speaking and oral skills. The study recommended teachers to make use of all available strategies and techniques to help students develop better speaking and oral production in English.

\subsection{Speaking in University Paradigm}

Learning English as a second or foreign language is essential to university students since English is the language of instruction in most disciplines. Developing speaking skills and being able to speak is an indicator of language improvement.

Classroom interaction is an intricate procedure in which the students and the teachers are lively exchange roles and turns. Therefore, poor management of classroom interaction especially speaking one affects the learning process in several ways such as inappropriate instructions by the teacher and being unable to take part in lesson activities (Al-Smadi \& Rashid, 2019). In classroom interactions, English language teachers negotiate the content with their students using students' thoughts, asking questions, offering directions, explaining or correcting students' talk. Students in this regard can imitate the teachers on how well to speak and debate carefully (Al-Smadi \& Rashid, 2017).

Hyland (1997) investigated adult students' speaking difficulties. The outcomes of that research have shown that speaking difficulties are associated with productive skills; that is, writing and speaking. Another study conducted by Evans and Green (2007) on learners at a higher educational institution showed that students' main difficulties in speaking were linked to grammar, fluency, and pronunciation.

\subsection{History of EMP}

English for Medical Purposes (EMP) first emerged in the 1960s (Maher, 1986) under the umbrella of (ESP) English for specific purposes (Antic, 2007; Dudley-Evans \& St John, 1998; McDonough, 1984). Maher (1986) stated that EMP is related to workers within health context and healthcare providers.

EMP has emerged to meet specific academic and professional needs of medical and medical linked learners. Medical language is a particular language purpose of providing resourceful interaction in the healthcare field. Since medical language is a unique language context, it can only be recognized by learning it in meaningful and contextual ways (Yeo, 2004). Lately, EMP has established its own disciplinary content, pedagogy, and research base. EMP contains the selection of authentic and interesting readings that are connected to the medical field and at the appropriate level for scholars (Skelton \& Whetstone, 2012). EMP focuses more on language in context than on teaching language structures and grammar (Skelton \& Whetstone, 2012). Also, it focuses on numerous medicine-related activities and materials (Porcaro, 2013).

\subsection{English Language in Saudi Arabia}

The extraction of oil in the Arab world, Specifically Saudi Arabia, gave rise and demanded the necessity to English language teaching (Javid et al., 2012). Learning English is required at the educational level and for getting a career (Bersamina, 2009).

In Saudi Arabia, English has become famous due to the popularity of internet and modernity (Elyas, 2008). The 
Saudi officials have put a lot of efforts to advance the quality of English language teaching and learning by sending students for higher education in universities and colleges in English-native countries such as USA, UK, Canada, Australia, and overseas (Shemary, 2008). Consequently, the English Language has become essential among Saudi younger generations, for their higher education as well as for their future careers.

\subsection{Speaking Difficulties}

Language teachers face considerable difficulties in helping students speak in classes; such as insufficient awareness, embarrassment, first language use, and most learners' unwillingness to participate (Tuan \& Mai, 2015). Students' insufficient awareness of the subject matter obstructs students' speaking as they have no knowledge about the topic of investigation which consequently affects their motivation to talk and participate. This is in line with Baker and Westrup (2003) and Rivers (1968) who confirm the idea that students face difficulties in speaking when they have no prior knowledge, limited terms and ideas regarding the topic.

Embarrassment is another difficulty which students suffer from in classrooms. Students are sometimes nervous and have fears to speak as a result of their thinking of criticism when making mistakes. According to Littlewood (2007), students are often subject to inhibitions and apprehension in language classrooms.

First language (L1) use according to (Tuan \& Mai, 2015) is another cause of speaking difficulties as students frequently use their first language to express ideas. According to Harmer (1991), students use first language when they have no knowledge about the speaking task. Also, teachers' negative role modelling where teachers use their native language in English language classrooms make students think it is ok to use their L1 since their teachers do the same.

Unwillingness to participate especially in large classrooms is another cause of speaking difficulties where most students have limited opportunity to speak or where the big chunk is occupied by few students who are willing to speak and participate.

\section{Research Methodology}

Adopting a two-cycle research, this study procedures were designed to collect mixed data to get the whole view of learners' perspectives concerning the English language main skills of listening, speaking, reading, and writing. The quantitative Cycle One came in an attempt to spot which skill(s) is/are the most essential for the participants and which one(s) is/are the most problematic. For the qualitative Cycle Two, the reasons that lie behind the problems found as well as solutions to these difficulties were discussed from the students' viewpoint.

\subsection{Instrumentation and Population}

This research was intended to be a survey screening EMP learners' language needs through self-reporting assessment of their own EFL skills as initial diagnosis of needs analysis. Based on the results of the first scope, the present study was then narrowed to identify obstacles confronting EFL tertiary students in mastering speaking skills, discussing solutions from the point of view of learners. To this end, two data collection tools were used with which both quantitative and qualitative data were collected to help have the grasp of the issue investigated.

Firstly, the quantitative data were collected from a personal-assessment report using SurveyMonkey as a platform. A 7-item questionnaire was self-developed by the researchers. Then, three academicians and three professionals were consulted for the validity of the items of the report. After that, the SurveyMonkey-based link was created and shared with 60 randomly chosen Saudi students who were enrolled in Level I at a medical college where mastering English skills in general and speaking in specific play a crucial role. Out of these 60 links distributed, 45 responses were recorded on the system scoring $75 \%$ of completion rate. However, for the 45 respondents, 44 of them answered all the 7 questions; whereas only one participant skipped four questions (Q1, 2, 4 , and 5) and answered the rest three ones. Data from the report were analysed using SurveyMonkey analytical tools.

Secondly, qualitative data were elicited from the focus group. After analysing the quantitative data from Cycle One, which had concluded that the speaking skill was deemed the most difficult as well as the most important for the participants, a guided focus group discussion was carried out during Cycle Two in order to unveil reasons and solutions for the issue of speaking inefficiency. Due to the anonymity ensured by SurveyMonkey where respondents' identities are not revealed, 10 participants were selected randomly from the population in order to hold the scheduled debate. The 10 target participants were invited for the interview via WhatsApp messages with the set date, appointment and location; nonetheless, 9 respondents attended the discussion, and only one did not show. The focus group debate was performed according to the set agenda of two main topics to discuss (Reasons $\&$ Solutions). The carried-out discussion was recorded with the attendance of three of the researchers' board to 
record, observe, and moderate the focus group. The moderators were familiar to the participants to avoid extraneous factors. Data from the group discussion were first encoded to be later thematically analysed and interpreted.

\section{Findings}

Each cycle was analysed and interpreted separately. The first cycle data were used to inform the technique to apply in Cycle Two since the second cycle topics to debate on depended mainly on the results from Cycle One stating the target skill deemed the most difficult and important.

\subsection{Results from the Questionnaire}

Data collected from the questionnaire were computed employing the calculation facilities equipped by SurveyMonkey. Each question of the seven items fell in one of three constructs-level of difficulty, importance, and improvement desire. Responses for each question are analysed below under the construct they fell in.

\subsubsection{Construct One Responses (Difficulty Index)}

Construct one was intended to identify the difficulty scale of each skill of listening with comprehension, speaking fluently and accurately, reading effectively, and writing correctly. Questions 1,2,3,4, and 5 fell in this construct. The results obtained are analysed below.

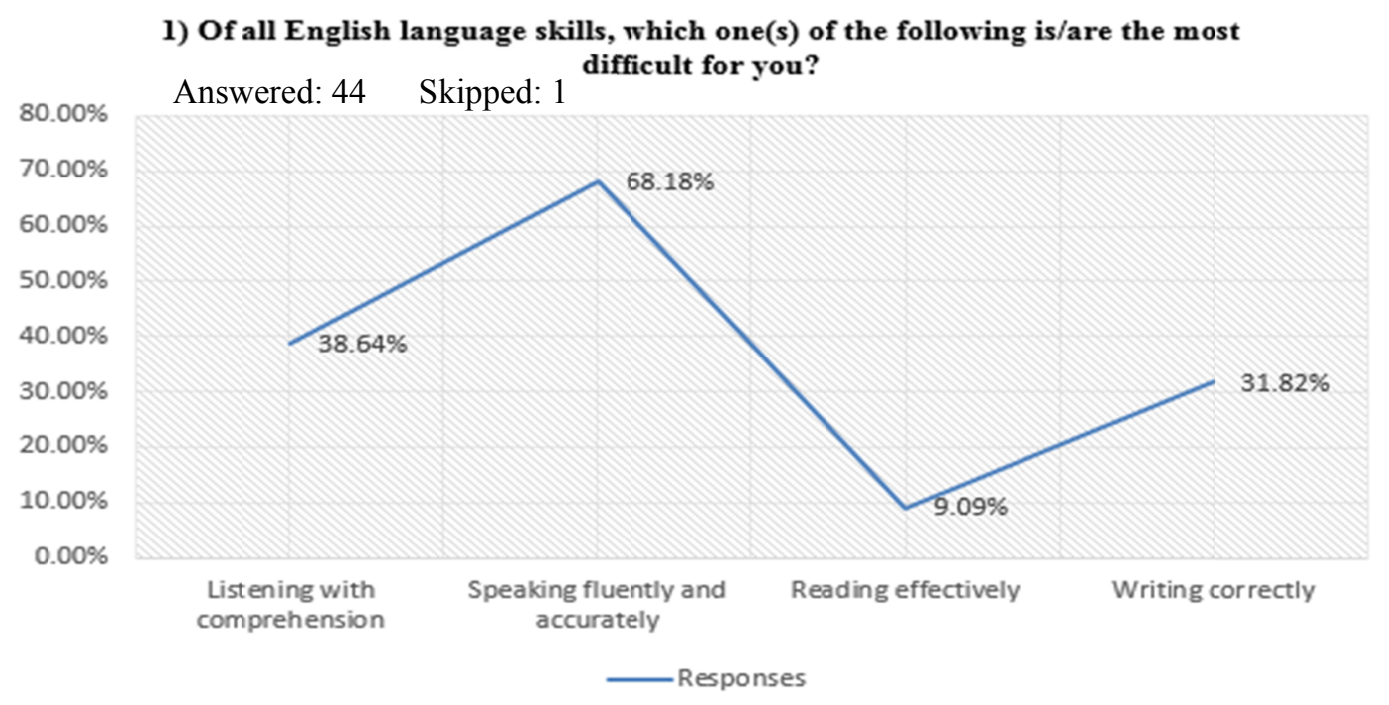

Figure 1. Q1 responses

Figure 1 sums up the data obtained from respondents' answers to Question 1. Together, Figure 1 and Table 1 present the detailed statistics for Q1 responses.

Table 1. Language skills difficulty index

\begin{tabular}{|c|c|c|c|c|}
\hline \multicolumn{3}{|c|}{ ANSWER CHOICES } & \multicolumn{2}{|c|}{ RESPONSES } \\
\hline \multicolumn{3}{|c|}{ Listening with comprehension (1) } & $38.64 \%$ & 17 \\
\hline \multicolumn{3}{|c|}{ Speaking fluently and accurately (2) } & $68.18 \%$ & 30 \\
\hline \multicolumn{3}{|c|}{ Reading effectively (3) } & $9.09 \%$ & 4 \\
\hline \multicolumn{3}{|c|}{ Writing correctly (4) } & $31.82 \%$ & 14 \\
\hline \multicolumn{5}{|c|}{ Total Respondents: 44} \\
\hline \multicolumn{5}{|c|}{ BASIC STATISTICS } \\
\hline Minimum & Maximum & Median & Mean & Standard Deviation \\
\hline 1.00 & 4.00 & 2.00 & 2.23 & 1.06 \\
\hline
\end{tabular}

Question One was intended to scan the overall report of the difficulty level of the target four skills. Q1 received 44 complete responses $(n=44)$ and a skipped one. For the question illustrated in Figure 1, participants can select 
more than one response to accommodate flexibility and freedom to respondents that is why the total percentage exceeded $100 \%$. Students click on the skill(s) that they find the most difficult for them. The results are further presented in Table 1. Based on the data computed, the results were 17(38.64\%) for listening with comprehension, $30(68.18 \%)$ for speaking fluently and accurately, $4(9.09 \%)$ for reading effectively, and $14(31.82 \%)$ for writing correctly. The mean score was estimated as 2.23 at 1.06 standard deviation.

\section{Q2: In terms of difficulty, could you please rate the "listening" skill?}

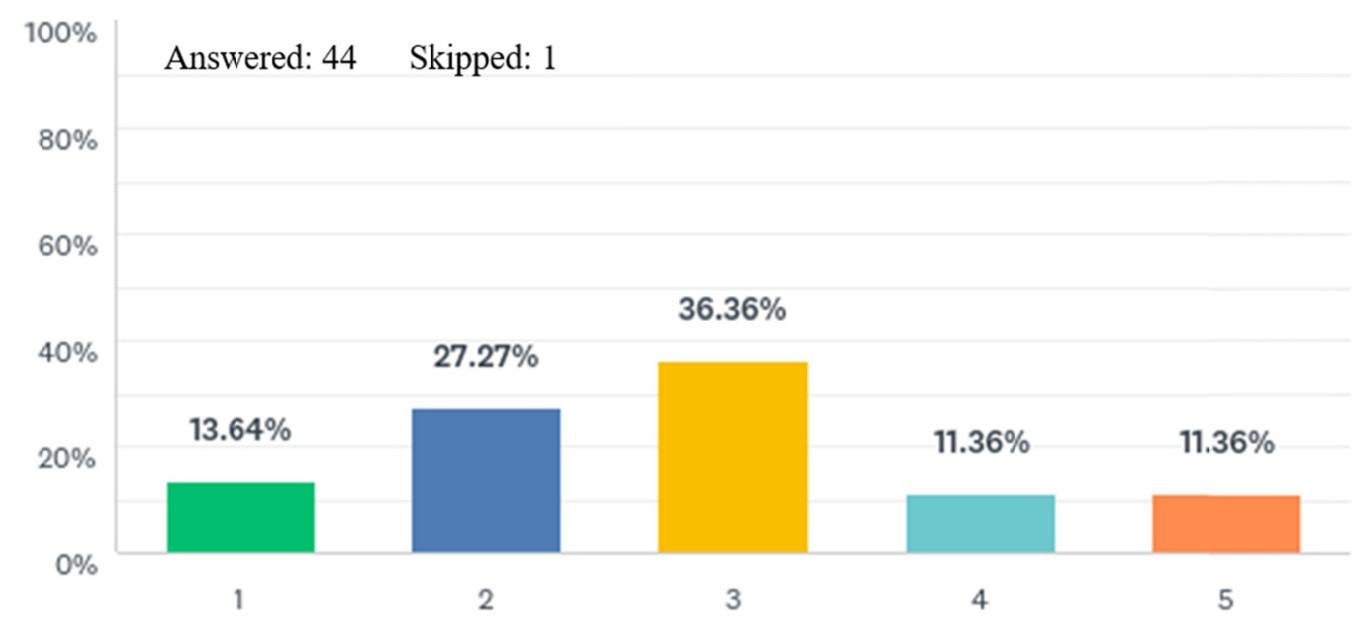

Figure 2. Q2 responses

Figure 2 illustrates the data got from Question 2 answers. Figure 2 besides Table 2 shed light on the responses obtained for Q2. The reference used was as follows: 1) for being very easy, 2) for being easy, 3) for being moderate, 4) for being difficult, and 5) for being too difficult.

Table 2. Listening difficulty scale

\begin{tabular}{|c|c|c|c|c|}
\hline \multicolumn{3}{|c|}{ ANSWER CHOICES } & \multicolumn{2}{|l|}{ RESPONSES } \\
\hline \multicolumn{2}{|c|}{$1(1)$} & \multicolumn{2}{|r|}{$13.64 \%$} & 6 \\
\hline \multicolumn{2}{|l|}{$2(2)$} & \multicolumn{2}{|r|}{$27.27 \%$} & 12 \\
\hline \multicolumn{2}{|l|}{$3(3)$} & \multicolumn{2}{|r|}{$36.36 \%$} & 16 \\
\hline \multicolumn{2}{|l|}{$4(4)$} & \multicolumn{2}{|r|}{$11.36 \%$} & 5 \\
\hline \multicolumn{2}{|l|}{$5(5)$} & \multicolumn{2}{|r|}{$11.36 \%$} & 5 \\
\hline \multicolumn{4}{|l|}{ Total } & 44 \\
\hline \multicolumn{5}{|c|}{ BASIC STATISTICS } \\
\hline Minimum & Maximum & Median & Mean & Standard Deviation \\
\hline 1.00 & 5.00 & 3.00 & 2.80 & 1.16 \\
\hline
\end{tabular}

After a quick scan using Q1, Questions 2, 3, 4, and 5 aim at collecting specific diagnosis of the four target skills to assess. In doing so, multi-clicks were disabled automatically. With a mean score of 2.80 at a standard deviation of $(\mathrm{SD}=1.16)$, Question Two responses $(\mathrm{n}=44)$ were calculated as presented in Figure 2 and Table 2. Q2 total answers were 44 complete responses, and a skipped one. In Q2, participants were asked to rate the difficulty level of listening as one of the main language skills. Only one response was allowed. Learners were briefed and pre-informed of the difficulty scale references. As depicted in Figure 2 and Table 2, responses rating the difficulty level of listening were $6(13.64 \%)$ for being very easy, $12(27.27 \%)$ for being easy, $16(36.36 \%)$ for being moderate, $5(11.36 \%)$ for being difficult, and $5(11.36 \%)$ for being too difficult. 


\section{Q3: In terms of difficulty, could you please rate the "speaking" skill?}

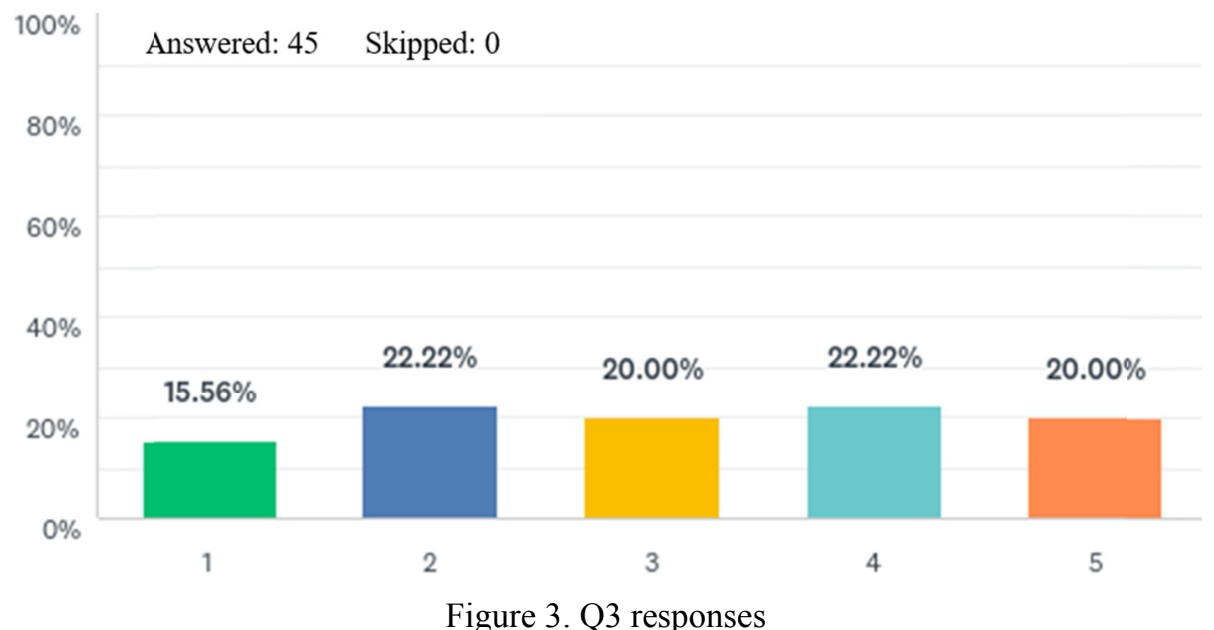

Figure 3 sums up the data obtained from respondents' answers to Question 3. Together, Figure 3 and Table 3 present the detailed statistics for Q3 responses.

Table 3. Speaking difficulty scale

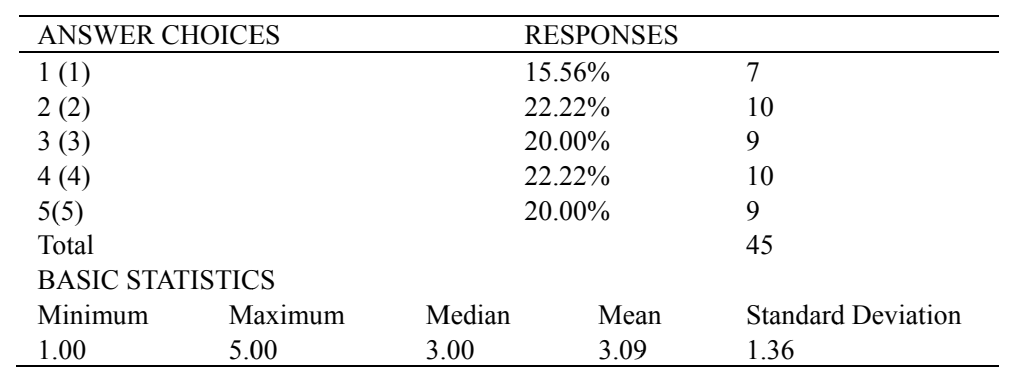

In Question Three, respondents $(\mathrm{n}=45)$ selected the number that represented their self-rating of speaking from 1 through 5 depending on the difficulty scale. Responses for Q3 were complete with no skipped ones. In Q3, participants were asked to rate the difficulty level of speaking with only one click. As presented in Figure 3 and Table 3, responses rating the difficulty level of speaking were $7(15.56 \%)$ for very easy, $10(22.22 \%)$ for easy, $9(20 \%)$ for moderate, $10(22.22 \%)$ for difficult, and $9(20 \%)$ for too difficult. The mean score for Q3 was 3.09 $(\mathrm{SD}=1.36)$.

\section{Q4: In terms of difficulty, could you please rate the "reading" skill?}

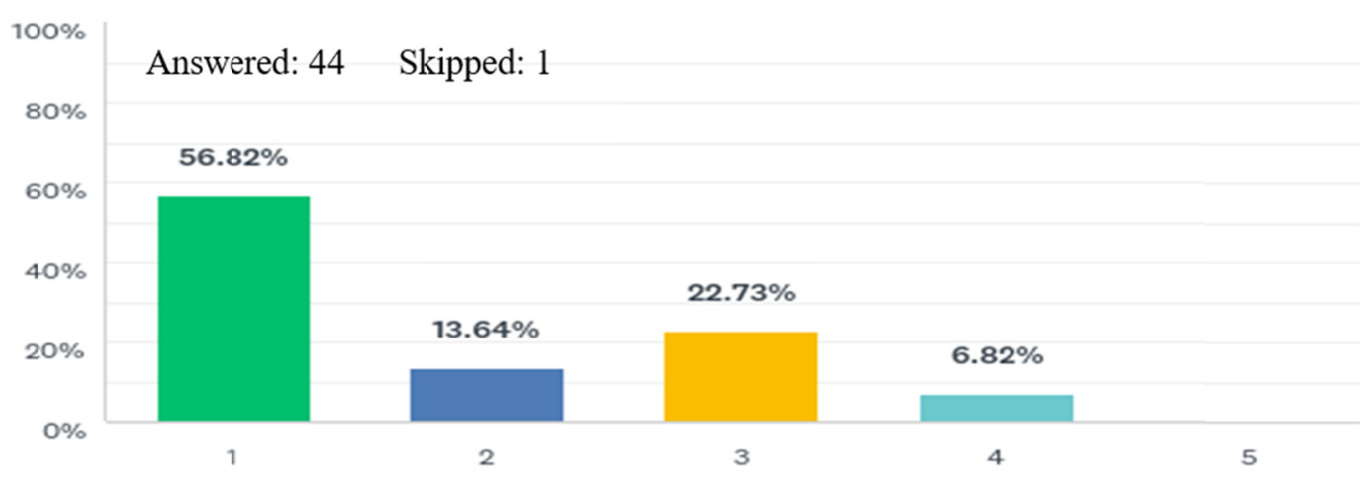

Figure 4. Q4 responses 
Figure 4 illustrates the data got from Question 4 answers to. Figure 4 beside Table 4 shed light on the responses obtained for Q4.

Table 4. Reading difficulty scale

\begin{tabular}{|c|c|c|c|c|}
\hline \multicolumn{3}{|c|}{ ANSWER CHOICES } & \multicolumn{2}{|l|}{ RESPONSES } \\
\hline \multicolumn{3}{|c|}{$1(1)$} & $56.82 \%$ & 25 \\
\hline \multicolumn{3}{|l|}{$2(2)$} & $13.64 \%$ & 6 \\
\hline \multicolumn{3}{|l|}{$3(3)$} & $22.73 \%$ & 10 \\
\hline \multicolumn{3}{|l|}{$4(4)$} & $6.82 \%$ & 3 \\
\hline \multicolumn{3}{|l|}{$5(5)$} & $0.00 \%$ & 0 \\
\hline \multicolumn{4}{|l|}{ Total } & 44 \\
\hline \multicolumn{5}{|c|}{ BASIC STATISTICS } \\
\hline Minimum & Maximum & Median & Mean & Standard Deviation \\
\hline 1.00 & 4.00 & 1.00 & 1.80 & 1.01 \\
\hline
\end{tabular}

With a mean score of $1.80(\mathrm{SD}=1.01)$, Question Four responses $(\mathrm{n}=44)$ were computed as illustrated in Figure 4 and Table 4. Q4 total answers were 44, and a skipped one. In Q4, participants were asked to rate the difficulty level of the reading skill. Only one answer was allowed. Learners were briefed and pre-informed of the scale references. As depicted in Figure 4 and Table 4, responses rating the difficulty level of reading were 25(56.82\%) for being very easy, $6(13.64 \%)$ for being easy, $10(22.73 \%)$ for being moderate, $3(6.82 \%)$ for being difficult, and none $(0 \%)$ for being too difficult.

\section{Q5 :In terms of difficulty, could you please rate the "writing" skill?}

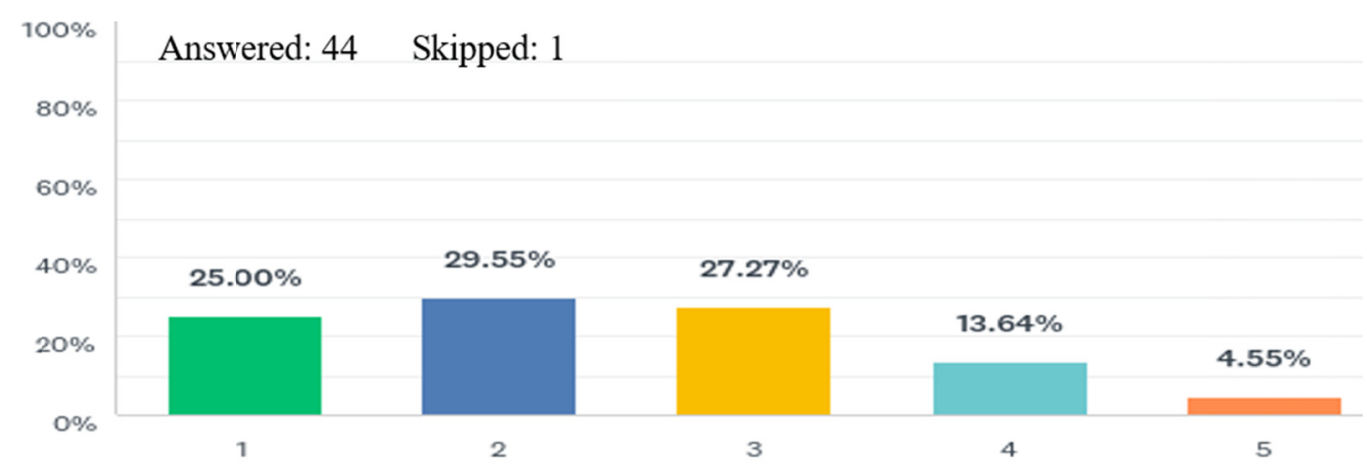

Figure 5. Q5 responses

Figure 5 sums up the data obtained from respondents' answers to Question 5. Together, Figure 5 and Table 5 present the detailed statistics for Q5 responses.

Table 5. Writing difficulty scale

\begin{tabular}{|c|c|c|c|c|}
\hline \multicolumn{3}{|c|}{ ANSWER CHOICES } & \multicolumn{2}{|l|}{ RESPONSES } \\
\hline \multicolumn{2}{|c|}{$1(1)$} & \multicolumn{2}{|r|}{$25.00 \%$} & 11 \\
\hline \multicolumn{2}{|l|}{$2(2)$} & \multicolumn{2}{|r|}{$29.55 \%$} & 13 \\
\hline \multicolumn{2}{|l|}{$3(3)$} & \multicolumn{2}{|r|}{$27.27 \%$} & 12 \\
\hline \multicolumn{2}{|l|}{$4(4)$} & \multicolumn{2}{|r|}{$13.64 \%$} & 6 \\
\hline \multicolumn{2}{|l|}{$5(5)$} & \multicolumn{2}{|r|}{$4.55 \%$} & 2 \\
\hline \multicolumn{4}{|l|}{ Total } & 44 \\
\hline \multicolumn{5}{|c|}{ BASIC STATISTICS } \\
\hline Minimum & Maximum & Median & Mean & Standard Deviation \\
\hline 1.00 & 5.00 & 2.00 & 2.43 & 1.14 \\
\hline
\end{tabular}

As shown in Figure 5 aided by Table 5, participants $(\mathrm{n}=44)$ rated the difficulty of the writing skill in their answers to Question Five on a scale of 1 to 5 with a mean score of 2.43 at 1.14 standard deviation. 
Respondents rated the difficulty level of the writing skill as being $11(25 \%)$ for very easy, $13(29.55 \%)$ for easy, $12(27.27 \%)$ for moderate, $6(13.64 \%)$ for difficult, and 2(4.55\%) for too difficult.

\subsubsection{Construct Two Responses (Importance Report)}

With one question (Q6), Construct Two came to highlight the skill that participants see as the most important for their current needs and future career and requirements. Students were asked to select only one from the target four language main skills of listening, speaking, reading, and writing.

\section{Q6: Which one of the following English language skills is the most important for you?}

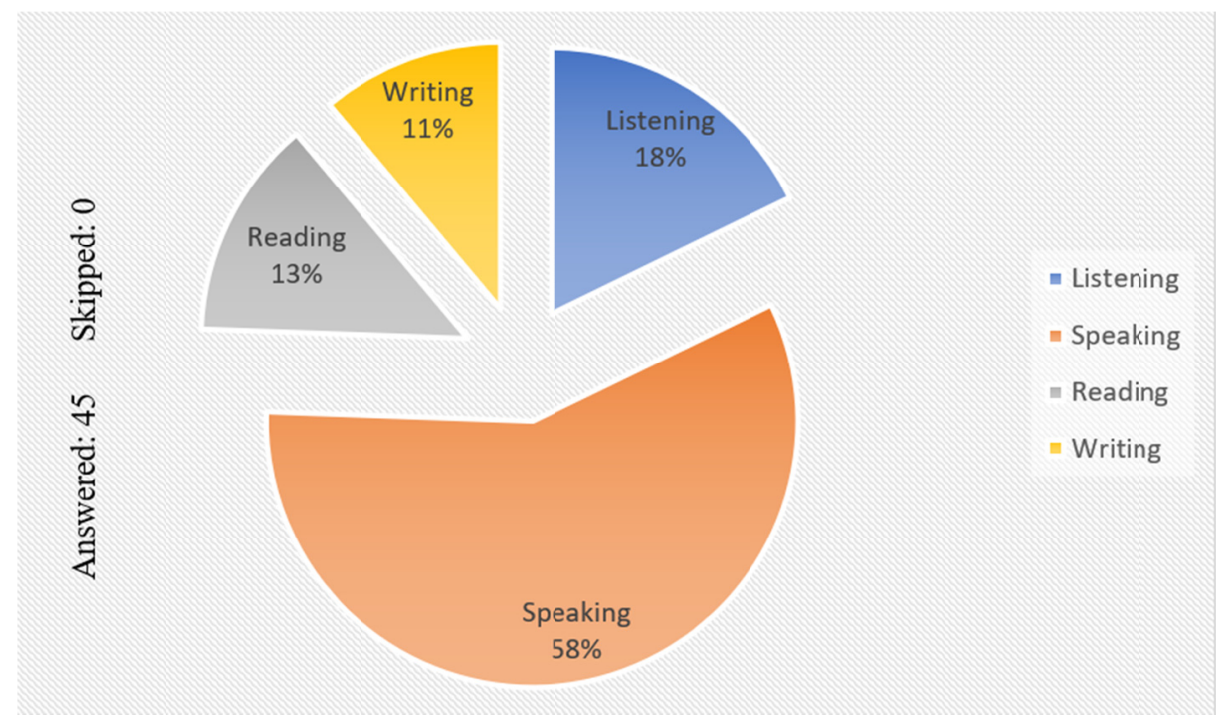

Figure 6. Q6 responses

Figure 6 illustrates the data got from Question 6 answers. Figure 6 side by side to Table 6 shed light on the responses obtained for Q6.

Table 6. Language skills importance index

\begin{tabular}{|c|c|c|c|c|}
\hline \multicolumn{3}{|c|}{ ANSWER CHOICES } & \multicolumn{2}{|l|}{ RESPONSES } \\
\hline \multicolumn{3}{|c|}{ Listening (1) } & $17.78 \%$ & 8 \\
\hline \multicolumn{2}{|l|}{ Speaking (2) } & & $57.78 \%$ & 26 \\
\hline \multicolumn{2}{|l|}{ Reading (3) } & & $13.33 \%$ & 6 \\
\hline \multicolumn{2}{|l|}{ Writing (4) } & & $11.11 \%$ & 5 \\
\hline \multicolumn{4}{|c|}{ Total } & 45 \\
\hline \multicolumn{5}{|c|}{ BASIC STATISTICS } \\
\hline Minimum & Maximum & Median & Mean & Standard Deviation \\
\hline 1.00 & 4.00 & 2.00 & 2.18 & 0.85 \\
\hline
\end{tabular}

Based on the data graphed in Figure 6 and presented in Table 6, each one of the four skills was assessed by respondents $(\mathrm{n}=45)$ in terms of how far it is important for them. At a standard deviation of 0.85 , the computed data were as follows: the listening skill got $8(17.78 \%)$, speaking received $26(57.78 \%)$, reading had $6(13.33 \%)$ while writing obtained only $5(11.11 \%)$ of the recorded responses.

\subsubsection{Construct Three Responses (Improvement Needs)}

The main purpose of Construct Three was to collect data from the participants concerning the skill or skills they find most in need of improvement for their current needs and future career and practices. Among the four target skills, respondents can click one skill or more based on their needs for improvement. Multi-choices option was enabled on respondents' choice for Q7 that fell in the third construct. 


\section{Q7: Which one(s) of the following English language skills do you need to improve?}

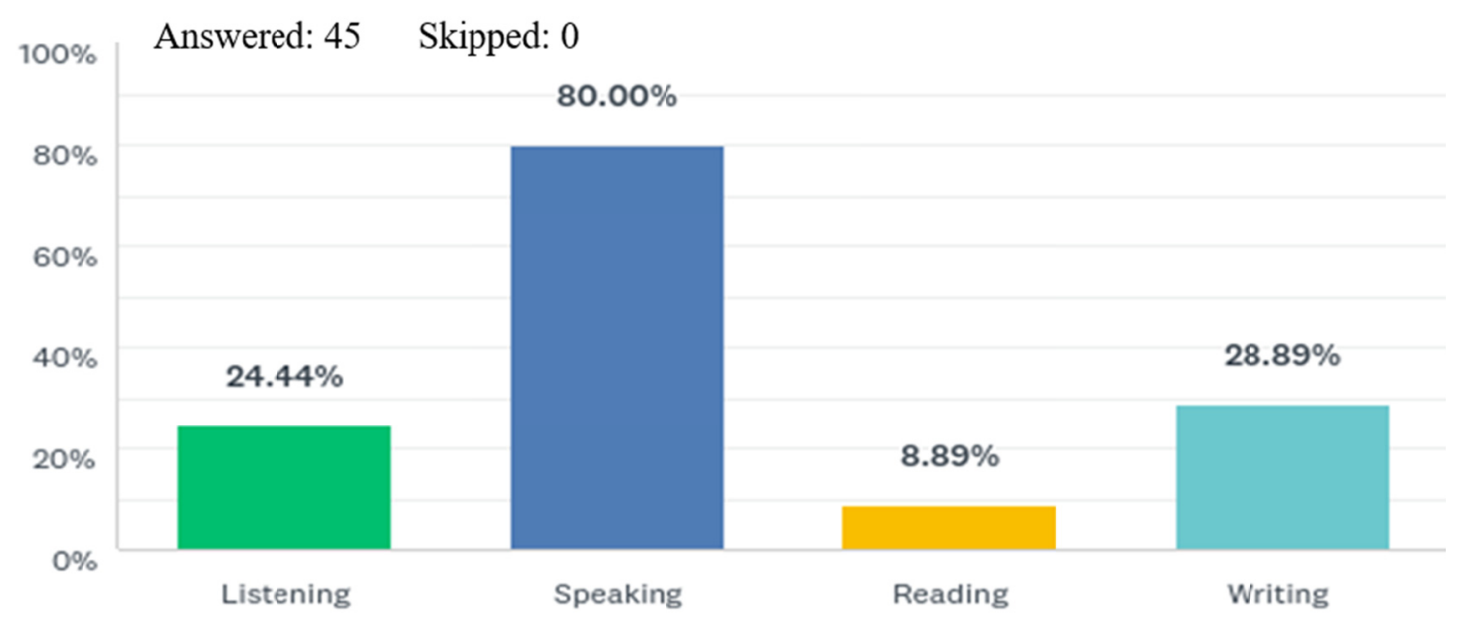

Figure 7. Q7 responses

As presented in Figure 7, respondents could choose the skill(s) that they need or plan to improve. Figure 7 sums up the data obtained from respondents' answers to Question 7. Together, Figure 7 and Table 7 present the detailed statistics for Q7 responses. Due to enabling more than one click on the system, the total percentage exceeded $100 \%$.

Table 7. Improvement needs

\begin{tabular}{|c|c|c|c|c|}
\hline \multicolumn{3}{|c|}{ ANSWER CHOICES } & \multicolumn{2}{|l|}{ RESPONSES } \\
\hline \multicolumn{3}{|c|}{ Listening (1) } & $24.44 \%$ & 11 \\
\hline \multicolumn{2}{|c|}{ Speaking (2) } & & $80.00 \%$ & 36 \\
\hline \multicolumn{2}{|c|}{ Reading (3) } & & $8.89 \%$ & 4 \\
\hline \multicolumn{2}{|l|}{ Writing (4) } & & $28.89 \%$ & 13 \\
\hline \multicolumn{5}{|c|}{ Total Respondents: 45} \\
\hline \multicolumn{5}{|c|}{ BASIC STATISTICS } \\
\hline Minimum & Maximum & Median & Mean & Standard Deviation \\
\hline 1.00 & 4.00 & 2.00 & 2.30 & 0.98 \\
\hline
\end{tabular}

As shown in Figure 7 aided by the calculations in Table 7, participants $(n=45)$ clicked on the skill they prefer to work more on to improve. Answers varied for each skill of listening, speaking, reading, and writing with a mean score of 2.30 ( $\mathrm{SD}=0.98$ ). Obtained data were calculated as follows: $11(24.44 \%)$ for listening, $36(80 \%)$ for speaking, 4(8.89\%) for reading, 13(28.89\%) for writing.

Nonetheless, by filtering responses $(n=45)$ in order to convey them into the true percentage of 100 , Microsoft Office Excel (Version 2016) was used to change into average. Based on the calculations depicted in Figure 8, the average for improvement desire was converted as follows: $(24.44 \%=17 \%)$ for listening, $(80 \%=56 \%)$ for speaking, $(8.89 \%=6 \%)$ for reading, $(28.89 \%=21 \%)$ for writing. 


\section{Q7: Which one(s) of the following English language skills do you need to improve?}

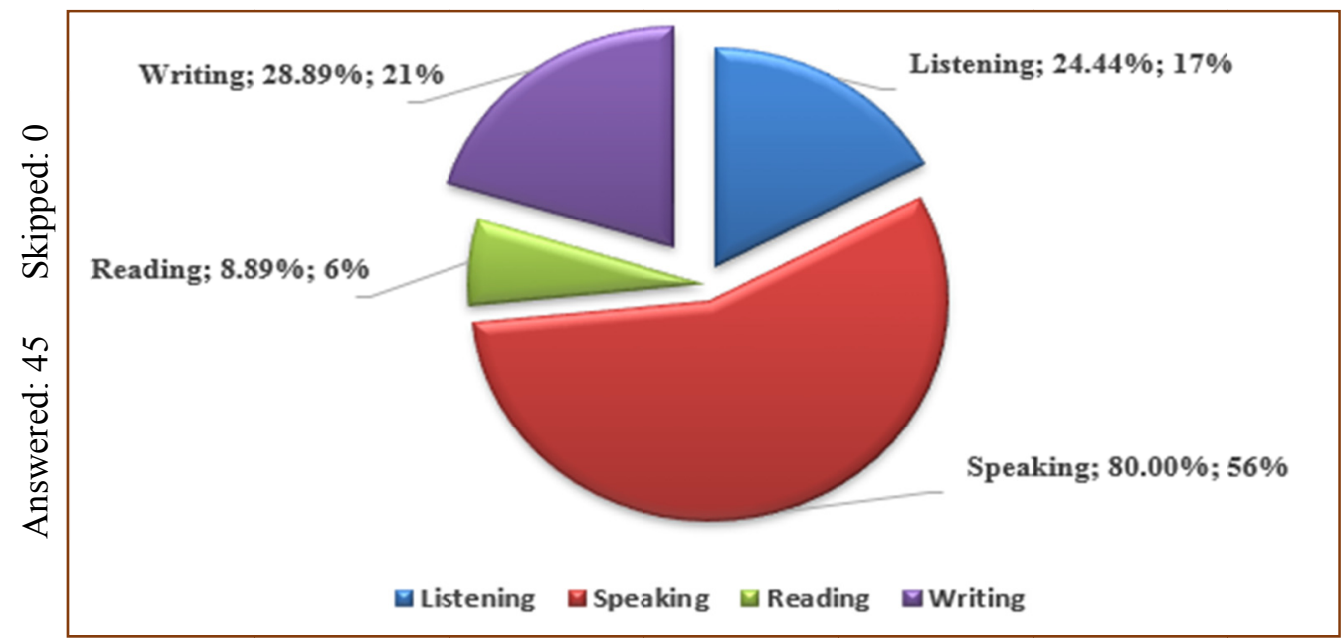

Figure 8. Q7 average

\subsection{Results from the Guided Focus Group}

The results of the first cycle informed the focus of Cycle Two on speaking fluently and accurately as the skill to further investigate. The second cycle came for deep exploration of reasons caused the problem of lacking speaking skills and discuss proposed solutions from the viewpoint of the target population.

For the reason set above, a debate was raised among nine participants randomly recruited to discuss freely causes and remedies. During the guided discussion, the data obtained were recorded and listed. After reaching an endpoint, the data were analysed to tabulate the reasons lie behind the problem of influent and inaccurate oral production of EFL students at a medical college.

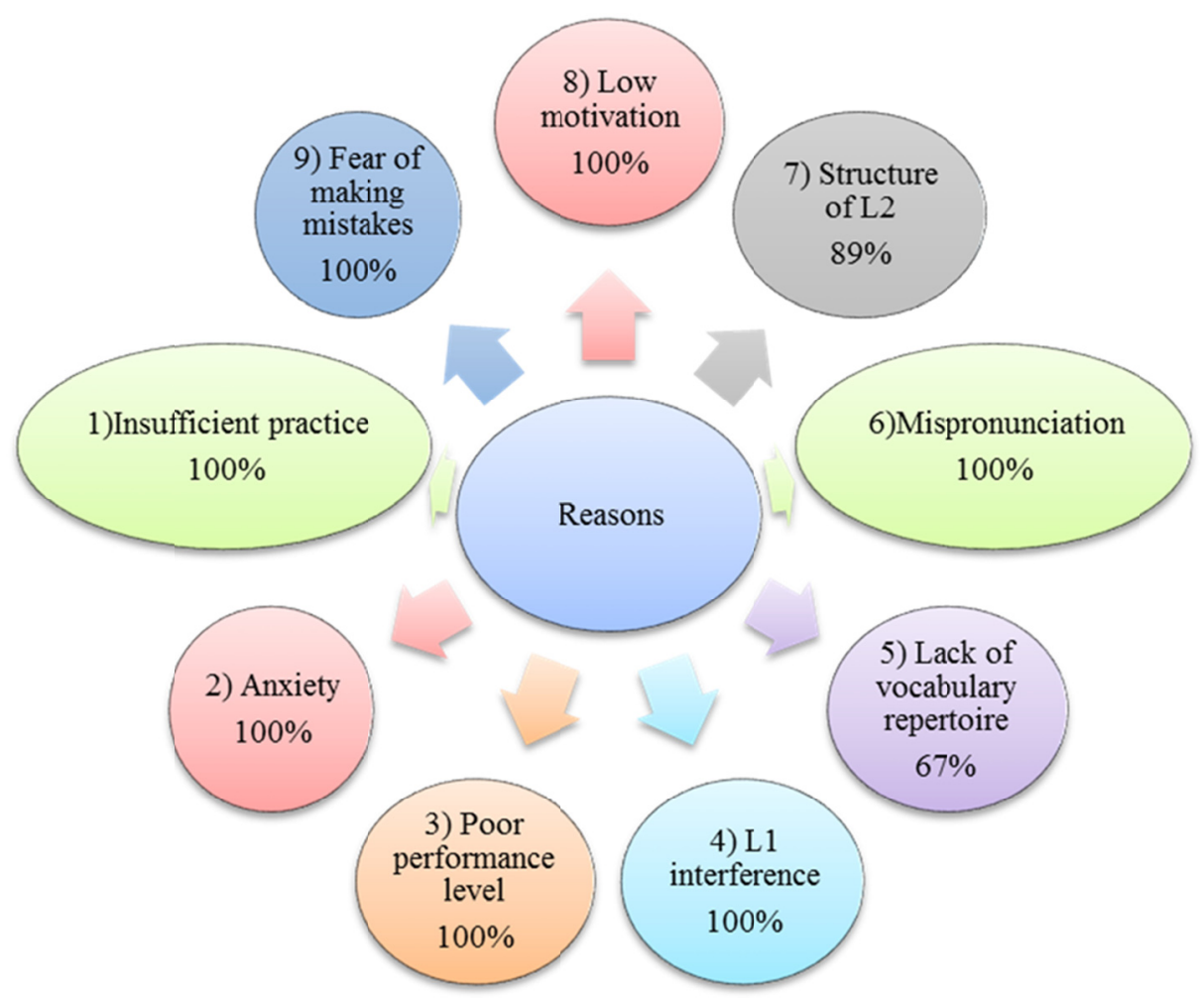

Figure 9. Reasons for speaking obstacles 
The reasons causing the issues of speaking for the EMP participants were elicited from the guided focus group discussion. The reasons graphed in Figure 9 were centred on 9 causes brainstormed by the group participants. Then, voting was held to frame the reasons found out by individuals within the focus group in order to check how far the whole group would agree on the reasons discussed. Findings from this debate were as follows: $9(100 \%)$ for insufficient practices, $9(100 \%)$ for stress and anxiety while speaking, $9(100 \%)$ for low level of oral production, $9(100 \%)$ for the gap between the native language of Arabic and the target language of English that influences the product of L2, 7 approximately (67\%) for the shortage of vocabulary repository, $9(100 \%)$ for incorrect pronunciation of L2, 8 about (89\%) for the difficulty of the L2 structure for EFL learners and the internal interpreter due to the interference of L1, 9(100\%) for the demotivation among EFL students because of some ineffective pedagogy, and $9(100 \%)$ for the fear of learners from making mistakes or errors. These factors work together contributing to the worsening of the speaking task for participants.

After summing up the reasons behind complicating the task of speaking in EFL as discussed by the group members, another topic was offered for them to debate on; solutions proposed by learners for overcoming the issue of speaking inefficiency. Students began discussing remedial works from their point of view. Most solutions were centred on compensating for the previous factors of more efficient live practice, memorizing vocabulary within conversations, drilling on fluent and correct pronunciation, less teacher-talk time (TTT) and much more student-talk time (STT), using the target language a medium of classroom interaction, watching movies, and using or developing internet software for improving speaking skills.

\section{Discussion}

Based on the findings presented in the previous section, it can be concluded that speaking fluently and accurately is the hardest mission for language learners, and it is the most important skill for the target medical-college students. This is based on the results of Cycle 1. In the first construct of difficulty index (Q1, 2, 3, 4, and 5), speaking got the highest score of (68.18\%) in Q1 responses. While other skills were rated for being 'difficult' and 'too difficult' as $(22.72 \%)$ with Mean score $(\mathrm{M}=2.80)$ for listening, $(6.82 \%)$ with $(\mathrm{M}=1.80)$ for reading, and (18.19\%) with ( $\mathrm{M}=2.43)$ for writing; however, speaking obtained (42.22\%) for being 'difficult' and 'too difficult' with the highest mean score $(M=3.09)$. This means that in terms of difficulty, speaking came first, then listening, writing, and finally reading. On the other hand, learners saw speaking as the most crucial skill for them as could be inferred from the results of the second construct (Q6) as well as the third construct (Q7); in which speaking had the highest percentage (58\%) in terms of importance, and (80\%) converted into average of (56\%) in terms of the need to improve. These results were similar to Hyland (1997) in terms of speaking to come first; while being in contrast with Hyland (1997) in terms of what was second. In Hyland (1997), writing came second on the difficulty scale; but in this study, the listening came second. This may be due to the properties of the EMP context for the present research.

In addition, Cycle Two informed that learners were deemed aware of their oral performance strengths and weaknesses while having a positive desire to exert more efforts to improve their level in speaking. The reasons elicited for affecting negatively learners' speaking performance were consistent with a bunch of relevant studies (Al-Jamal \& Al-Jamal, 2014; Gan, 2012; Rabab'ah, 2005; Soomro \& Farooq, 2018; Tuan \& Mai, 2015). EMP learners are in need of rich effective drilling and practice of various oral aspects, and more STT in and out of classrooms as well as using the target language more often; urging for the use of L2 as the main medium in language classrooms. This conclusion came at par with various previous studies that called for applying various techniques and using modern technology as aids to foster learners' oral production (e.g., Almoaily, 2019; Rashid et al., 2017; Yusof \& Abugohar, 2017).

In sum, oral production was concluded to be the most difficult and the most essential skill for EMP learners in their current needs and future requirements.

\section{Conclusion}

This self-rated report of language learners' needs informed that EFL students' oral performance is problematic from their view. This conclusion results in recommending further planning from all stakeholders and teachers to adopt, adapt and innovate new teaching and learning techniques that help improve students' language skills in general and speaking in particular. Planned Drilling and motivating learners are also effective in this regard.

Teachers are encouraged to vary their pedagogies, tools, and aids that lead to desirable learning outcomes. Techniques and tools that make students more active and engaged into language learning in a practice-rich and less-stressful environment are moreover recommended. Plus, integrating technology and the Internet are expected to maintain student-centred education settings fulfilling these objectives. 


\section{References}

Abugohar, M. A., \& Yunus, K. (2018). Difficulties encountered by Arab students in pronouncing English correctly. International Journal of Education \& Literacy Studies, 6(4), 93-100. https://doi.org/10.7575/aiac.ijels.v.6n.4p.93

Al-Jamal, D. A., \& Al-Jamal, A. A., (2014). An investigation of the difficulties faced by EFL undergraduates in speaking skills. English Language Teaching, 7(1),19-27.

Almoaily, M. (2019). Language policy and power in out-of-classroom EFL contexts: The case of English departments in Saudi Arabian higher education institutions. International Journal of English Linguistics, 9(2), 136-144. https://doi.org/10.5539/ijel.v9n2p136

Al-Smadi, O., \& Rashid, R, A. (2017). A theoretical review of classroom discourse. International Journal of Academic Research In Progressive Education And Development, 6(3), 164-173. https://doi.org/10.6007/IJARPED/v6-i3/3169

Al-Smadi, O. A., \& Rashid, R. A. (2019). Teacher talk in an English for medical purposes classroom. Trends in Social Sciences, 1(1), 57-63.

Antic, Z. (2007). Forward in teaching English for medical purposes. Medicine and Biology, 14(3), 141-147.

Baker, J., \& Westrup, H. (2003). Essential speaking skills: A handbook for English language teachers. London: Continuum.

Bashir, M., Azeem, M., \& Dogar, A. H. (2011). Factors affecting students' English speaking skills. British Journal of Arts and Social Sciences, 2(1), 34-50.

Bersamina, F. V. (2009). English as a second language (ESL) learners in Saudi Arabia. Associated Content Society. Retrieved from http://www.associatedcontent.com

Brown, G., \& Yule, G.(1983). Teaching the spoken language. Cambridge: Cambridge University Press.

Bueno, A., Madrid, D., \& McLaren, N. (2006). TEFL in secondary education. Granada: Editorial Universidad de Granada.

Chaney, A. L., \& Burk, T. L. (1998). Teaching oral communication in grades K-8. Boston: Allyn \& Bacon.

Clifford, R. T. (1987). Language teaching in the federal government: A personal perspective. Annals, AAPSS, 490. https://doi.org/10.1177/0002716287490001010

Davies, P., \& Pearse, E. (2000). Success in English teaching. Oxford: Oxford University Press.

Dudley-Evans, T., \& St John, M. J. (1998). Developments in English for specific purposes: A multi-disciplinary approach. Cambridge: Cambridge university press.

Elyas, T. (2008) The attitude and impact of the American English as a global language within the Saudi educational system. Novitas Roral, 2(1), 28-48.

Evans, S., \& Green, C. (2007). Why EAP is necessary: A survey of Hong Kong tertiary students. Journal of English for Academic Purposes, 6, 3-17. https://doi.org/10.1016/j.jeap.2006.11.005

Gan, Z. (2012). Understanding L2 speaking problems: Implications for ESL curriculum development in teacher training institution in Hong Kong. Australian Journal of Teacher Education, 37(1), 43-59. https://doi.org/10.14221/ajte.2012v37n1.4

Gilakjani, P. (2016). English pronunciation instruction. Literature Review, 1(1),1-6.

Harmer, J. (1991). The practice of English language teaching (3rd ed.). London: Longman.

Harmer, J. (2007). The practice of English language teaching. London: Longman company.

Hedge, T. (2000). Teaching and learning in the language classroom. Oxford: Oxford University Press.

Howarth, P. (2001). Process speaking: Preparing to repeat yourself. MET, 10(1), 39-44.

Hughes, R. (2002). Teaching and researching speaking. New York: Pearson Education.

Hyland, K. (1997). Is EAP necessary? A survey of Hong Kong undergraduates. Asian Journal of English Language Teaching, 7, 77-99.

Izadi, M. (2015). Understanding teachers' and learners' perceptions of English speaking difficulties: An investigation of gender effect. Modern Research Studies: An International Journal of Humanities and Social Sciences, 2(2), 227-247. 
Javid, C. Z., Farooq, M. U., \& Gulzar, M. A. (2012) Saudi English-major undergraduates and English teachers' perception regarding effective ELT in the KSA: A comparative study. European Journal of Scientific Research, 85(1), 55-70.

Kabir, U. S. (2014). Challenges of speaking in Bangladeshi classrooms. Unpublished Master of Arts in TESOL.

Le, T. M. (2011). An investigation into factors that hinder the participation of university students in English speaking lessons. Vietnam: University of Languages and International Studies.

Leong, L., \& Ahmadi, S. M. (2017). An analysis of factors influencing learners' English-speaking skills. International Journal of Research in English Education, 2(1), 34-41. https://doi.org/10.18869/acadpub.ijree.2.1.34

Littlewood, W. (2007). Communicative language teaching. Cambridge: Cambridge University Press.

Luama, S. (2004). Assessing speaking. Cambridge: Cambridge University Press. https://doi.org/10.1017/CBO9780511733017

Maher, J. (1986). English for medical purposes. Language Teaching, 19(2), 112-145. https://doi.org/10.1017/S0261444800012003

Mazouzi, S. (2013). Analysis of some factors affecting learners' oral performance: A case study with 3rd Year Pupils of Menaa's Middle Schools. M. A. Dissertation, Department of Foreign Languages, English Division, Faculty of Letters and Languages, Mohamed Khider University of Biskra, People's Democratic Republic of Algeria.

McDonough, J. (1984). ESP in perspective: A practical guide. New York: Routledge/Taylor \& Francis.

Ngo, P. T. (2011). A study on the difficulties in learning speaking English of the first year students at the Faculty of Information Technology, Thai Nguyen University. MA Thesis, Thai Nguyen University, Thailand.

Nguyen, T., \& Tran, M. (2015). Factors affecting students'speaking performance at Le Thanh Hien high school. Asian Journal of Educational Research, 3(2), 8-23.

Nunan, D. (1995). Language teaching methodology: A textbook for teachers. NY: Phoenix Ltd.

Porcaro, J. W. (2013). Teaching English for science and technology: An approach for reading with engineering English. English Teaching Forum, 51(2), 32-39.

Rabab'ah, G. (2005). Communication problems facing Arab learners of English. Journal of Language and Learning, 3(1), 180-197.

Rashid, R., Mohammed, S., Rahman, M., \& Shamsuddin, S. (2017). Developing speaking skills using Virtual Speaking Buddy. International Journal of Emerging Technologies in Learning, 12(5), 195-201. https://doi.org/10.3991/ijet.v12i05.6955

Richards, J. C. (1990). Conversationally speaking: Approaches to the teaching of conversation. In C. Jack Richards (Ed.), The language teaching matrix (pp. 67-85). New York: Cambridge University Press. https://doi.org/10.1017/CBO9780511667152.006

Rivers, W. M. (1968). Teaching foreign language skills. Chicago: University of Chicago Press.

Shemary, A. (2008). Saudi Arabia: US preferred destination for students, Asharq Alawsat. Retrieved from $\mathrm{http} / / / \mathrm{www}$.asharq-e.com/news.asp?section=7\&id=11331

Skelton, J. R., \& Whetstone, J. (2012). English for medical purposes and academic medicine: Looking for common ground. Ibérica: Revista de la Asociación Europea de Lenguas para Fines Específicos, 24, 87102.

Soomro, A. F., \& Farooq, M. U. (2018). EFL learners' attitude towards developing speaking skills at the University of Taif, Saudi Arabia. International Journal of English Linguistics, 8(3), 318-327. https://doi.org/10.5539/ijel.v8n3p318

Thornbury, S. (2005). How to teach speaking. In J. Harmer (Ed). London: Longman.

Tuan, N. H., \& Mai, T. N. (2015). Factors affecting students' speaking performance at LE Thanh Hien High School. Asian Journal of Educational Research, 3(2), 8-23.

Ur, P. (1996). A course in language teaching. Cambridge: Cambridge University Press.

Yeo, S. (2004). Language barriers and access to care. Annual Review of Nursing Research, 23, 59-76. 
Yusof, N., \& Abugohar, M. A. (2017). Teachers' attitudes towards the use of extracurricular activities in enhancing students' speaking skills. International Journal of Academic Research in Progressive Education and Development, 6(3), 153-163. https://doi.org/10.6007/IJARPED/v6-i3/3168

\section{Copyrights}

Copyright for this article is retained by the author, with first publication rights granted to the journal.

This is an open-access article distributed under the terms and conditions of the Creative Commons Attribution license (http://creativecommons.org/licenses/by/4.0/). 